Please cite: Holt, A. (2017). Parricide in England and Wales (1977-2012): An exploration of offenders, victims, incidents and outcomes. Criminology \& Criminal Justice, 1748895816688332.

\title{
Parricide in England and Wales (1977-2012): An exploration of offenders, victims, incidents and outcomes
}

\begin{abstract}
:
The killing of one's parents is a neglected area in criminological scholarship, particularly in the UK, and this article presents the first national analysis of parricide in England and Wales. It draws on data from the Home Office Homicide Index to examine all recorded cases of parricide over a 36-year period and examines the characteristics of offenders, victims, incidents and court outcomes. The implications of these findings are discussed in relation to two particular dominant theoretical ideas within the field: the role of mental illness in parricide, and the notion that there are distinct forms of violence against parents that can be organised along dimensions of chronological age (i.e. juvenile/adult offender) and whether the violence is fatal (i.e. parricide) or non-fatal. The article concludes with a discussion of its wider implications for future research.
\end{abstract}

Key Words: Parricide; Matricide; Patricide; Homicide Index; Violence 
Parricide refers to the killing of one's mother or father ${ }^{1}$, whether through a single violent incident or a culmination of abuse and/or neglect. It is a homicide dynamic that is rarely examined in the United Kingdom, and it tends to only enter public discourse as a cause celebre (e.g. the case of Jeremy Bamber in England in 1985') and in fictionalised and/or psychoanalytic narratives (e.g. Oedipus Rex). Furthermore, media reports of parricide tend to focus on those that feature multiple victims or that involve perpetrators who are juveniles (Boots and Heide, 2006). Historically, parricides have been constructed as aggravated murders, on a par with regicide, and would receive particularly severe judicial sentences in response (Walker, 2016). Yet despite its significance, the knowledge that we do have about parricides in the UK is confined to a handful of studies that have drawn on small clinical samples to examine the role of mental illness in parricide (e.g. Green, 1981; Akuffo et al, 1991; Baxter et al, 2001). While useful, these studies tell us little about the overall prevalence, variations in trends, and general offender, victim and offence characteristics of parricide. The present article aims to address this research gap and, in doing so, to challenge some of the dominant theories that have been instrumental in shaping academic discourse on parricide.

\section{Parricide: A Review of the Theory and Literature}

Theories of parricide have so far been dominated by research from the United States and, more specifically, have developed from Heide's work in the 1990s. In her 1992 book, Why Kids Kill Parents, Heide offered an analysis of adolescent parricide offenders (APOs) through her clinical case work as a forensic psychotherapist. Heide's (1992) development of a 'typology of parricide' is expressed in her claim that 'parricide is committed by three types of individuals: (1) the severely abused child (2) the severely mentally ill child and (3) the dangerously antisocial child' (Heide, 1992: 6). Notwithstanding the definitional slippage between offenders who are adolescents (from whom her evidence is based) and all offenders, Heide's model has been very influential in shaping the theoretical parameters of parricide research, and in particular the notion that parricide can be explained through the psychopathology of the offender. Much subsequent research has reinforced this discourse by focusing on mental illness as a significant factor in the perpetration of parricide (see Hillbrand et al, 1999 for a review). More recent research has examined different kinds of mental illness and their role in different parricidal contexts. For example, in her analysis of parricide offenders from a secure hospital in Finland, Liettu et al (2009) found that significantly more offenders who killed their mothers suffered from a psychotic disorder, while those who killed their fathers suffered from a personality disorder. Such findings led Liettu (2009) to suggest that there are different psychopathological contexts to matricide and patricide, with those who kill their mothers suffering from more severe mental illness including delusional beliefs (see also Weisman and Sharma, 1997).

\footnotetext{
${ }^{1}$ As Heide and Petee (2007a) point out, technically the term refers to the killing of a close relative, but it is now more commonly used in its narrower definition. The research literature also refers to patricide (the killing of one's father) and matricide (the killing of one's mother).

${ }^{2}$ This case involved the homicide of 25 year-old Bamber's father, mother, sister and two nephews in Essex, England, 1985. Bamber was convicted of their murder in 1986.
} 
Heide (2013) later suggested that mental illness is more dominant in adult offenders, the 'severely abused' type is more commonly found in adolescent offenders, and the 'dangerously antisocial' type is found in both adult and adolescent offenders (Heide, 2013: 9). While this demarcation between adolescent and adult offenders represents a step towards a more developmental approach to parricide theory, there is little nuance offered here. Furthermore, any potential developmental links between non-fatal violence towards parents (of which there has been much academic and policy interest over the past five years) and fatal violence towards parents have not been pursued theoretically, with each category of violence tending to be dismissed as representing a specific type coming from a distinct population (e.g. see Heide, 1992; Walsh and Kreinert, 2009).

In terms of research that has explored broader national patterns of offender, victim and incident characteristics, the most comprehensive analyses of parricide are those which draw on the incident-based Supplemental Homicide Report (SHR) data from the United States (US). These detailed arrest data are collected by law enforcement agencies and are collated by the Federal Bureau of Investigation (FBI). The SHR data covers approximately $92 \%$ of all estimated homicides in the US and its structure has remained almost unchanged since its last major revision in 1976 (Fox and Swatt, 2009). Such analyses are revealing: it is estimated that parricides constitute less than $2 \%$ of all homicides where the relationship is known (Boots and Heide, 2006) and 13\% of all family homicides (Diem and Pizarro, 2010). In the US, parricides appear to be declining over time along with all violent crime (Heide and Petee, 2007a), including parricides perpetrated by juveniles ${ }^{3}$ (Walsh et al, 2008). However, parricides as a proportion of all family homicides are increasing in the US: parricides constituted $13.2 \%$ of all family homicides in 2005 and $16.2 \%$ of all family homicides in 2013 (FBI, 2016). Other countries have reported varying rates and characteristics. For example, a review of all coroners' case files (1990-2005) in Quebec, Canada found that parricide constituted $9 \%$ of all domestic homicides (Bourget et al, 2007). In Australia, the most recent report (2010/11/12) from the National Homicide Monitoring Program (NHMP), which collects police and coroners' records, found that parricides constitute $12 \%$ of all domestic homicides (Bryant and Cusson, 2015).

In terms of victimisation, the US data suggest that slightly over half of victims are fathers (55\%) and victims' ages range widely (from 27 to 98 years), with typical victims aged 50-59 years (Heide and Petee, 2007a). In Australia, 52\% of victims are female, victims have a mean age of 59 years, and $9 \%$ of incidents involve multiple offenders (Bryant and Cusson, 2015). Analysis of the Police Crime Analysis System (2006-2013) in South Korea found that parricides constitute a relatively high $5 \%$ of all homicides, with the most common age of victims being 70 years and over (Jung et al, 2014). In Japan (1989-1995), parricide features more female victims (56\%) and, while like South Korea, the most common age of victims is 70 years and over, this age-range risk is particularly acute for female victims (Finch, 2001).

In terms of offenders, the US data found that over three-quarters are male (86\%) and range between 7 and 78 years of years. In the US, a fifth (21\%) of offenders are juveniles (i.e. aged 17 years or younger) and a substantial proportion (31\%) are under the age of 20 (Heide and

\footnotetext{
${ }^{3}$ To avoid confusion between the two meanings of 'child' (i.e. the offspring of the parent and the low chronological age of the offender), the term 'juvenile' is used to denote those aged 17 years and under (who are defined as 'child' in the latter sense by the United Nations Convention on the Rights of the Child).
} 
Petee, 2007a). In comparison, less than $6 \%$ of offenders in South Korea are under 20 years of age (Jung et al, 2014). In the US, the percentage of Black offenders is much higher than the proportion of Black people represented in the general population, but is much lower than the percentage of Black people who are arrested for all homicides (Heide and Petee, 2007a). Patricides are most likely to involve firearm weapons (i.e. handguns), while matricides are most likely to involve non-firearm weapons (i.e. knives) (Heide and Petee, 2007b). Offenders who are juveniles are significantly more likely to use firearms compared with adult-perpetrators, something which has been explained in terms of the 'physical strength hypothesis': that is, juveniles' relatively limited physical strength means they resort to firearms to overpower their parents (Heide and Petee, 2007a).

While each of these studies identifies some of the fascinating characteristics and contexts of parricide, very few studies provide national samples of coverage, track changes over time or use data which records outcomes following conviction. There have also been frequent reports of coding errors and, in particular, a lack of 'data cleaning' by researchers who use the SHR data (Parkin and Gruenewald, 2015), raising queries over the veracity of the data. Furthermore, we do not know the extent to which any of the findings from the international literature apply to England and Wales, a jurisdiction which is characterised by a moderate homicide rate for Western Europe ${ }^{4}$ and which is subject to its own political, cultural, historical and institutional milieu. This article aims to address this gap by presenting the first national analysis of parricide in England and Wales. The analysis that follows examines its general prevalence, the characteristics of victims and offenders (in terms of gender, age, ethnicity and dynamic of parricide), incident characteristics (in terms of intoxication, circumstances and method of killing), and court outcomes for offenders (in terms of conviction outcome and court disposal). Following this empirical analysis, this article discusses the findings in relation to their contribution to key theoretical developments in this field.

\section{Method}

This article is based on the statistical analysis of data from the Home Office Homicide Index (HI). The $\mathrm{HI}$ is compiled from 'homicide returns' that are completed for every offence initially recorded as 'homicide' by all police services across England and Wales. These data record socio-demographic information about victim and suspect(s), incident detail and outcome data. For this study, all recorded cases of parricide over a complete 36-year period (January 1977-December 2012) were identified. ${ }^{5}$ The Homicide Index is a victim-based recording system, and all parricide cases were identified using the category 'relationship to

\footnotetext{
${ }^{4}$ England and Wales has a homicide rate of 1.17 per 100,000 inhabitants, which ranks it midway amongst countries that are members of the European Union (Eurostat, 2014).

${ }^{5}$ Three separate datasets covered this 36-year period and were amalgamated. Some categories that were included in the later two datasets (i.e. from 1996 onwards) were not included in the first dataset, including whether the victim was a parent or step-parent, the ethnicity of the offender, and intoxication data. Thus, some of the findings that follow that draw on these categories only present data from 1996 (where indicated).
} 
suspect' and selecting those cases coded 'parent' (which includes adoptive parents) and 'step-parent'. 6

The selected cases were exported into an SPSS file and 'data cleaning' involved checking for missing/anomalous data, removing records where the homicide itself took place outside of the 36-year period, and cross-matching and aligning the categories of the dataset. Cases were excluded where the 'principal suspect' was acquitted at trial or where there was insufficient evidence to proceed to trial (and thus the case could not be considered a 'parricide'). However, a case was retained if it did not proceed to trial because of the death of the suspect or because the suspect was unfit to plead.

There were a number of parricides which featured multiple suspects. However, the HI only records the relationship of victim to 'principal suspect': 'non-principal suspects' are also categorised as having that same relationship, regardless of whether the victim was their parent (or step-parent). Therefore, these 'non-principal suspects' ( $n=32$ ) were excluded from the main offender-based analyses $(n=693)$, but the cases of multiple-offender parricides were included in the victim-level analyses $(n=716)$ and incident-level analyses $(n=693)$. Statistical analysis comprised descriptive analyses of the key offender, victim and incident variables and inferential tests for use with nominal data (i.e. Pearson's chi-square test and Fisher's exact test) were applied to examine the statistical significance of these variations. ${ }^{7}$ The level of statistical significance was set at $p<0.05$, using phi and Cramer's $V$ to measure the strength of association (using 95\% confidence levels). The analysis that follows focuses on the characteristics of the parricide offender and victim, in terms of gender, age, ethnicity and incident dynamic; the context of the parricide incident, in terms of intoxication levels, circumstances of offence and method of killing; and court outcomes, in terms of conviction outcome and court disposal.

\section{Findings: Parricide in England and Wales (1977-2012)}

Over the 36 year-period (1977-2012), there were 693 incidents of parricide recorded in England and Wales, suggesting a mean of approximately 19 incidents per year. This constitutes $3 \%$ of all homicides in England and Wales. These incidents involved 716 victims, with 23 incidents (approximately 3.3\% of incidents) involving 'double parricides' (i.e. the killing of both parents). This included one double parricide that also involved multiple offenders. Approximately $4.6 \%$ of incidents involved at least one other 'non-principal'

\footnotetext{
${ }^{6}$ Step-parents were not identified in the Home Office dataset prior to 2004. They constituted approximately $10 \%$ of all parents killed in parricides between 2004 and 2012.

${ }^{7}$ There is some debate in the statistical literature as to whether statistical testing is appropriate for administrative data, which typically consists of a complete census or population of all cases. Graubard and Korn (2002) refer to the two competing paradigms as administrative (essentially descriptive of the complete dataset) and scientific (where the interest is in drawing inferences about the underlying stochastic model which generates the data). Taking a scientific approach, Aitkin et al (2009: 29) suggest that any complete population can be viewed as a sample from a random (stochastic) process generating the data, and this random process will also generate future years of data not yet collected. A scientific approach is adopted in this article, as its interest is in distributional differences between sub-populations that may exist in the stochastic process and will manifest themselves in future years of data.
} 
offender, a proportion that is much lower compared with homicides more generally, where just over a fifth of incidents (21\%) involve multiple offenders (Office for National Statistics (ONS), 2014). ${ }^{8}$ Parricide then, represents a rather intimate form of killing.

Despite the general downward trend in homicides that has been observed since 2002/03 across England and Wales, including domestic homicides (ONS, 2014), there has been no significant rise or fall in parricides over the 36-year period, though there are certainly fluctuations, varying from a high of 27 victims in 1997 to a low of 11 victims in 2006. Taken as a proportion of the population of England and Wales during each Census year, the rate of parricides has remained stable, at approximately 0.04 victims per 100,000 population per year. ${ }^{9}$ Offenders who are juveniles (i.e. aged $10-17$ years) constitute approximately $9 \%$ of all principal suspects of parricide.

\section{The Offenders and Victims of Parricide}

\section{Gender, Age, Ethnicity and 'Incident Dynamic'}

Table 1 (below) compares male and female offenders in relation to gender, age, ethnicity and 'incident dynamic' (i.e. single or multiple victims and/or offenders). Like all forms of homicide, the main perpetrators of parricide are male, featuring in $90 \%$ of cases. There is no significant association between gender of offender and whether a single-victim or double parricide is committed. However, almost a third of parricides that involve multiple offenders involve females as the 'principal offender', and there is a significant relationship between the offenders' gender and whether other offenders are involved. In the United States, where similar findings have emerged (Heide, 2013), analysis of the corresponding news reports suggest that girls and women may be more likely to recruit boyfriends and partners to help them carry out the killing of their parent (Fegadel and Heide, 2015).

Table 1. Offender and Victim Characteristics of Parricide: England and Wales (1977-2012)

\begin{tabular}{llll}
\hline & $\begin{array}{l}\text { Male-perpetrated } \\
\text { Parricides }(n=622)\end{array}$ & $\begin{array}{l}\text { Female-perpetrated } \\
\text { Parricides }(n=71)\end{array}$ & $\begin{array}{l}\text { All Parricides } \\
(n=693)\end{array}$ \\
\hline $\begin{array}{l}\text { Victim characteristics } \\
\text { Father }\end{array}$ & $53 \%$ & $44 \%$ & $51 \%$ \\
Mother & $47 \%$ & $56 \%$ & $49 \%$ \\
$\begin{array}{l}\text { Ethnicity } \\
\text { White }\end{array}$ & & \\
$\quad$ Black & $83 \%$ & $89 \%$ & $84 \%$ \\
Asian & $8 \%$ & $6 \%$ & $8 \%$ \\
Age & $7 \%$ & $3 \%$ & $7 \%$ \\
$\quad$ Mode & & & $50-59$ years \\
Mean & $50-59$ years & $70-79$ years & 60.5 \\
Range & 60 & 65 & $25-101$ \\
& $25-101$ & $34-91$ & \\
\hline $\begin{array}{l}\text { Offender } \\
\text { characteristics }\end{array}$ & & & \\
Age & & & \\
\hline
\end{tabular}

\footnotetext{
${ }^{8}$ The overall homicide data reported in this article is derived from the Homicide Index and was collated and reported by the ONS (2014). This report covers a nine-year period (2003/04-2012/13) and includes all currently-recorded homicides (including those without suspects, those acquitted etc). The comparisons reported here need to be interpreted with these differences in mind.

${ }^{9} 1981=0.04$ per 100,000; $1991=0.04$ per 100,000; $2001=0.03$ per 100,000; $2011=0.05$ per 100,000
} 


\begin{tabular}{llll}
\hline Mode & $20-29$ years & $20-29$ years & $20-29$ years \\
Mean & 31 & 34 & 31 \\
Range & $11-69$ & $14-60$ & $11-69$ \\
& & & \\
\hline $\begin{array}{l}\text { Dynamic of incident } \\
\text { Single/Double parricide } \\
\text { Single victim }\end{array}$ & $96 \%$ & $99 \%$ & $97 \%$ \\
$\begin{array}{l}\text { Double victim } \\
\text { Lone/Multiple }\end{array}$ & $4 \%$ & $1 \%$ & $3 \%$ \\
perpetrators* & & & \\
Acted alone & $96 \%$ & $87 \%$ & $95 \%$ \\
Acted with others & $4 \%$ & $13 \%$ & $5 \%$
\end{tabular}

*Fishers exact test between acting alone/with others and gender of perpetrator: $p=0.003$ (1-sided). No other significant associations were found.

In terms of victimisation, there is a curious dynamic at play here that makes parricide distinct from both overall homicide (where males are the more likely victims, with an overall gender ratio of 68:32) and from domestic homicide (where females are the more likely victims, with an overall gender ratio of 30:70) (ONS, 2014). In parricide, the gender of victims is evenly distributed, with a ratio of 51:49 (fathers: mothers), a pattern consistent across the international literature. While Table 1 indicates a tendency for female offenders to kill their mothers, and for male offenders to kill their fathers, this is not statistically significant.

Alongside gender, age is a crucial contextual variable in parricide cases because age differentials are so central to the relationship between victim and offender. Table 1 reveals that parricides involve families at every stage of their lifecycle, with very wide age ranges found in both offenders (11-69 years; mean age $=31$ years) and victims (25-101 years; mean age $=60.5$ years). However, while men and women are equally likely to be the victims of parricide, this does not hold across the lifecycle: most men are killed by their offspring when in their 50s and most women are killed by their offspring when in their 70s. Thus, while the '70 years and over' age-range is generally considered to be a 'low-risk' age range for overall homicide victimisation (constituting only $8 \%$ of all homicide victims) (ONS, 2014), it is certainly not 'low-risk' for matricide victimisation: $37 \%$ of female victims were 70 years or over compared with $29 \%$ of male victims, which is a significant association $(\chi 2=21.046$, phi= $-0.171 ; \mathrm{df}=1, \mathrm{p}=0.00)$.

In terms of ethnicity, the post- 1996 data ${ }^{10}(n=342)$ found that $84 \%$ of victims were White; $7 \%$ were Asian (Indian sub-continent) and $8 \%$ were Black. The percentage of parricide victims recorded as White is slightly higher than those found in the overall homicide data (77\%) and it more broadly reflects the overall White population (86\%) in England and Wales (ONS, 2012). To some extent, this suggests that parricide rates of victimisation do not under-represent the White population to the same extent that general homicide

\footnotetext{
${ }^{10}$ Ethnicity was not recorded in the Homicide Index prior to 1996. Ethnicity across England and Wales has inevitably changed since this time, and the population data reported here is from the most recent Census (2011). Also note that the Census uses self-identifying categories, while the Homicide Index records victim ethnicity based on visual identification.
} 
victimisation does. ${ }^{11}$ However, the proportion of parricide victims recorded as Black is nevertheless almost three times as high when compared with the overall Black population at $3 \%$, suggesting at least some degree of racialisation in parricide victimisation.

\section{Parricide Characteristics and Juvenile Perpetrators}

Table 2 (below) compares adult and juvenile perpetrators in relation to victim gender, victim age and incident dynamic. The data suggests that there are distinct gendered contours of juvenile-perpetrated parricide, with a statistically significant association found between whether the perpetrator is an adult or juvenile, and the gender of the victim (i.e. juveniles are more likely to kill fathers). Such differences raise intriguing questions about the extent to which adolescent fatal and non-fatal violence towards parents is part of the same continuum, given that most non-fatal juvenile violence towards parents is against mothers by a ratio of $80: 20$ (Condry and Miles, 2014). ${ }^{12}$ This is a point to which we return. However, no other significant associations were found between adult and juvenile offenders (e.g. in incident dynamic or victim age).

Table 2. Adult v. Juvenile Perpetrators of Parricide: England and Wales (1977-2012)

\begin{tabular}{|c|c|c|}
\hline & $\begin{array}{l}\text { Adult-perpetrated Parricides } \\
(n=629)\end{array}$ & $\begin{array}{l}\text { Juvenile-perpetrated Parricides } \\
(n=64)\end{array}$ \\
\hline \multicolumn{3}{|l|}{ Victim gender* } \\
\hline Father & $50 \%$ & $68 \%$ \\
\hline Mother & $50 \%$ & $32 \%$ \\
\hline \multicolumn{3}{|l|}{ Victim Age } \\
\hline Mode & $50-59$ years & $40-49$ years \\
\hline Mean & 62 & 45 \\
\hline Range & $25-101$ & $34-70$ \\
\hline \multicolumn{3}{|l|}{ Dynamic of incident } \\
\hline \multicolumn{3}{|l|}{ Single/double victim } \\
\hline Single victim & $93 \%$ & $97 \%$ \\
\hline Double victim & $7 \%$ & $3 \%$ \\
\hline \multicolumn{3}{|c|}{ Lone/multiple offenders } \\
\hline Lone offender & $96 \%$ & $91 \%$ \\
\hline Multiple offender & $4 \%$ & $9 \%$ \\
\hline
\end{tabular}

\section{The Contexts of Parricide Incidents in England and Wales}

The HI data (1996-2012) show that $14 \%$ of victims and 35\% of offenders were intoxicated at the time of the killing(s). For offenders, this is almost double the proportion found in all homicides in England and Wales (Miles, 2012) and it raises important questions about the unique context of parricides that make them distinct from other homicides.

\footnotetext{
${ }^{11}$ Homicide victims (and, inevitably, suspects) are recorded as Black in $11 \%$ of all homicides in England and Wales (ONS, 2014)

${ }^{12}$ There appears to be no existing data about the gendered nature of adults' non-fatal violence towards parents to enable us to make similar speculations.
} 


\section{Main circumstances of offence}

Table 3 (below) compares the 'main circumstances of the offence' between male and female victims. This is a rather broad category and police officers must select from a range of codes that cover antecedents of the incident (e.g. 'result of arson'), assumed motive (e.g. 'jealousy/possessiveness') or source of conflict (e.g. 'pub fight, argument over girlfriend'). There is also an 'other' option. As Table 3 shows, the police made much use of the 'circumstances not elsewhere specified' code, recorded in $31 \%$ of parricides, and the 'unknown' code, recorded in almost $15 \%$ of parricides. To some extent, reliance on these default codes is characteristic of all homicides ${ }^{13}$, resulting in a category that is less insightful that it could be (see Mayhew, 2001). However, with almost half of all parricides (i.e. 46\%) relying on these two codes alone, it does suggest that police officers do not yet know how to construct parricide incidents and that the current available options do not easily map onto the circumstances the police see before them. ${ }^{14}$

Table 3. Circumstances of Parricides in England and Wales (1977-2012)

\begin{tabular}{|c|c|c|c|}
\hline Circumstances & $\begin{array}{l}\text { All } \\
\text { victims } \\
(n=716)\end{array}$ & $\begin{array}{l}\text { Male } \\
\text { victims } \\
(n=368)\end{array}$ & $\begin{array}{l}\text { Female } \\
\text { victims } \\
(n=348)\end{array}$ \\
\hline Circumstances not elsewhere specified & $31 \%$ & $37 \%$ & $25 \%$ \\
\hline Irrational act $*$ & $24 \%$ & $14 \% *$ & $35 \% *$ \\
\hline Other domestic dispute & $19 \%$ & $23 \%$ & $15 \%$ \\
\hline Unknown & $15 \%$ & $14 \%$ & $16 \%$ \\
\hline Mercy killing & $2 \%$ & $2 \%$ & $3 \%$ \\
\hline Jealousy/ possessiveness & $2 \%$ & $3 \%$ & $1 \%$ \\
\hline Resulting from an offence of arson & $1 \%$ & $1 \%$ & $2 \%$ \\
\hline Other circumstances (e.g. pub fight) & $1 \%$ & $2 \%$ & $>1$ \\
\hline Other financial gain (not related to domestic dispute) & $1 \%$ & $1 \%$ & $2 \%$ \\
\hline Other circumstances (e.g. neighbour, feud) & $1 \%$ & $2 \%$ & $>1$ \\
\hline Other & $1 \%$ & $1 \%$ & $1 \%$ \\
\hline Killed for financial gain & $>1$ & $1 \%$ & - \\
\hline Prevent victim informing on or testifying against suspect & $>1$ & $>1$ & $>1$ \\
\hline Robbery & $>1$ & $>1$ & $>1$ \\
\hline Accusations of infidelity & $>1$ & $>1$ & - \\
\hline Burglary & $>1$ & $>1$ & - \\
\hline $\begin{array}{l}\text { Motor vehicle } \\
\text { Sexual }\end{array}$ & $>1$ & $>1$ & - \\
\hline \multirow[t]{2}{*}{ TOTAL } & $>1$ & - & $>1$ \\
\hline & 100 & 100 & 100 \\
\hline
\end{tabular}

${ }^{*}$ Chi-square test between gender of victim and irrational act circumstance: $\chi^{2}=40.592, p h i=-0.238 ; \mathrm{df}=1$, $p=0.00)$.

Outside of these default codes, the most frequently-used code in parricides is 'Irrational act (carried out by insane or disturbed individual)', which is used in almost a quarter of

\footnotetext{
${ }^{13}$ 'Circumstances not elsewhere specified' features in 15\% of all homicides (and in 10\% of homicides where the victim knows the offender) and 'Unknown' features in $25 \%$ of all homicides (and in $19 \%$ of homicides where the victim knows the offender) (ONS, 2014).

${ }^{14}$ The category 'Main circumstances - other' is available for the police to make additional notes about particular incidents. Data are not recorded in this category for $90 \%$ of parricides, but where comments have been made, they illuminate the diversity of sources of conflict that are presumed to be at the root of parricidal encounters: examples include 'Angry regarding childhood neglect', 'Argument over use of cooker' and 'Victim was suffering with Alzheimer's'.
} 
parricides (24\%). This code is used to denote a homicide presumed to be the product of mental disturbance and its usage in parricides is almost six times higher than its use in homicide generally (ONS, 2014). However, 'irrational act' is used significantly more in parricides that involve adult offenders compared with juvenile offenders ( $24 \%$ vs. $8 \%$; $\chi^{2}=$ 10.646, phi $=0.124 ; d f=1, p=0.001) .{ }^{15}$ Furthermore, significantly more one-on-one parricides (26\%) were recorded as an 'irrational act' compared with parricides where other participants (whether as offenders or victims) were involved ( $9 \%$ of such parricides) $(x 2=10.220$, $p h i=-0.119 ; d f=1, p=0.001)$.

While there are no significant differences in the assumed circumstances of the parricide between male and female offenders, there are differences between male and female victims. As indicated in Table 3, there is a statistically significant association between the gender of the victim and the use of 'irrational act' as the main circumstance, with this category more frequently used with female victims (35\%) compared with male victims (14\%). Perhaps unsurprisingly, there is also a significant association between the age of the victim and the recorded circumstance of 'Mercy killing' ${ }^{16}$, with victims over 70 years of age statistically more likely to be recorded as such ( $p=0.00$, fishers exact test).

\section{Method of Killing}

Table 4 (below) highlights the 'Method of Killing' in cases of parricide, comparing male and female offenders. As indicated, the most frequent method of causing death in parricides is use of a sharp or blunt instrument (60\%), a method that is more frequently used than in general homicides (43\%) (ONS, 2014). The relative frequency of methods that involve intimate contact in parricides should not be overlooked, nor indeed should the frequency of such methods that are neither quick nor painless. Methods of killing can reveal motive in family homicides (Daly and Wilson, 1994) and the extensive pain and suffering produced by sharp or blunt objects suggest a presence of rage and an absence of care in parricidal encounters. Few parricide deaths involve the culmination of abuse or neglect, particularly with male perpetrators: 'causing death by negligence or neglect' was found in $4.2 \%$ of female-perpetrated parricides and in $0.9 \%$ of male-perpetrated parricides. This may be something of a surprise given the lifetime prevalence rate of $3.4 \%$ for elder abuse in the UK (O'Keefe et al, 2007).

Table 4. Method of Killing in Parricides: England and Wales (1977-2012)

\begin{tabular}{llll}
\hline Method of Killing (Top 6 only) & All Parricides & $\begin{array}{l}\text { Male- } \\
\text { perpetrated }\end{array}$ & $\begin{array}{l}\text { Female- } \\
\text { perpetrated }\end{array}$ \\
\hline Sharp or blunt instrument & $60 \%$ & $60 \%$ & $60 \%$ \\
Strangulation, asphyxiation & $16 \%$ & $15 \%$ & $19 \%$ \\
Shooting * & $7 \%$ & $7 \% *$ & $1 \% *$ \\
Kicking or hitting (with or without weapon) & $10 \%$ & $10 \%$ & $7 \%$ \\
\hline
\end{tabular}

\footnotetext{
${ }^{15}$ There were no other significant associations found between adult/juvenile status of the offender and presumed 'circumstances'. However, 'Mercy killing', 'Burglary', 'Accusations of fidelity', 'Robbery' and 'Sexual' are categories that have never been used in juvenile-perpetrated parricides.

16 'Mercy killing' is a term that is generally no longer used in English law, but refers to the act of ending another's life out of a perceived sense of compassion due to ongoing suffering experienced by the victim (e.g. through terminal illness). It can act as a mitigating factor in cases of homicide (see Criminal Justice Act, 2003).
} 


\begin{tabular}{llll}
\hline Not known & $1 \%$ & $6 \%$ & $3 \%$ \\
Other $^{17}$ & $6 \%$ & $6 \%$ & $10 \%$
\end{tabular}

*Fishers exact test of association between shooting and gender of perpetrator: $p=0.038$ (1-sided)

Method of Killing and Firearms: Cases involving Juvenile Perpetrators and Double Parricides

As indicated in Table 4, shooting was identified in $7 \%$ of all parricides, a method that is statistically significantly favoured by male-perpetrators. Table 5 (below) compares method of killing between adult and juvenile perpetrators. While proportionately more victims were indeed killed by firearms in parricides perpetrated by juveniles compared with adultperpetrated parricides ( $11 \%$ vs. $6 \%$ ), this difference is not statistically significant, suggesting little support for Heide's 'physical strength hypothesis' in this particular context (where, compared with the US, there is a relative lack of access to firearms). Table 5 highlights how juveniles are, like their adult counterparts, most likely to use a sharp or blunt instrument (found in $71 \%$ of such parricides). This raises intriguing questions about how juvenile perpetrators do compensate for their reduced physical strength during parricidal encounters. It has been speculated that juveniles tend to kill when their parents are defenceless, for example when sleeping (e.g. Grattagliano et al, 2015). Unfortunately, such contextual detail is absent from existing police homicide returns.

Table 5. Method of Killing in Adult v. Juvenile Perpetrators of Parricide: England and Wales (1977-2012)

\begin{tabular}{lll}
\hline & $\begin{array}{l}\text { Adult-perpetrated Parricides } \\
(n=629)\end{array}$ & $\begin{array}{l}\text { Juvenile-perpetrated Parricides } \\
(n=64)\end{array}$ \\
\hline Method of Killing & & $71 \%$ \\
Sharp or blunt instrument & $59 \%$ & $5 \%$ \\
Strangulation, asphyxiation & $17 \%$ & $11 \%$ \\
Shooting & $6 \%$ &
\end{tabular}

A further question regarding the use of firearms in parricides concerns cases of 'double parricide'. Only $3 \%$ of all parricide incidents involve a double parricide which, as a proportion, is half as much as those reported in the United States (Heide and Petee, 2007b). One reason for this difference may be the greater use of firearms in US-parricides (and in the US generally): firearms make it easier to kill more than one victim in a single incident compared with other methods of killing. Table 6 (below) compares 'Method of Killing' in cases of single-victim parricides and double-victim parricides. While the most common methods used in 'double parricides' also involve sharp and blunt instruments (as with singlevictim parricides), such parricides are significantly associated with shooting (22\%) compared with single-victim parricides (6\%). In contrast, there are no significant differences in method of killing between single-offender and multiple-offender parricides.

\footnotetext{
17 'Other' includes arson, negligence/neglect, burning/scalding, causing to fall against hard surface, struck by motor vehicle, drowning and poisoning.
} 
Table 6. Method of Killing in Single and Double Parricides in England and Wales (1977-2012)

\begin{tabular}{llll}
\hline Method of Killing (Top 6 only) & All victims & Single victim & Double victim \\
\hline Sharp or blunt instrument & $60 \%$ & $60 \%$ & $64 \%$ \\
Strangulation, asphyxiation & $16 \%$ & $16 \%$ & $5 \%$ \\
Shooting * & $7 \%$ & $6 \% *$ & $22 \% *$ \\
Kicking or hitting (with/without weapon) & $10 \%$ & $10 \%$ & $5 \%$ \\
Not known & $1 \%$ & $1 \%$ & $0 \%$ \\
Other & $6 \%$ & $7 \%$ & $4 \%$
\end{tabular}

*Fishers exact test of association between single/double victim parricide and shooting: $\mathrm{p}=0.01$ (1 sided)

\section{Court Outcomes for Parricides in England and Wales}

\section{Court convictions for cases of parricide}

Table 7 (below) indicates the court outcomes for parricide cases for the period 1996 to 2012 in England and Wales. ${ }^{19}$ As indicated, a conviction for homicide (i.e. murder or manslaughter) dominates the outcomes, featuring in $80 \%$ of all parricide cases. While this figure reflects the conviction rate for homicide more generally where a person has been unlawfully killed (ONS, 2014), there are intriguing differences within this category. In particular, the use of 'diminished responsibility' as a partial defence constitutes $24.2 \%$ of homicide convictions in parricide cases but only $5.5 \%$ of overall homicide conviction outcomes (ONS, 2014). It is also noteworthy that $4 \%$ of all parricide offenders were deemed unfit to plead or declared not guilty due to reasons of insanity - a percentage that is over nine times higher than in overall homicides (0.4\%) (ONS, 2014). No significant associations were found between particular court outcomes and the gender of the perpetrator.

Table 7. Court outcomes for Parricide cases in England and Wales (1996-2012)

\begin{tabular}{|c|c|c|c|}
\hline & $\begin{array}{l}\text { Male-perpetrators } \\
(n=299)\end{array}$ & $\begin{array}{l}\text { Female-perpetrators } \\
(n=36)\end{array}$ & $\begin{array}{l}\text { All } \\
\text { perpetrators } \\
(n=335)\end{array}$ \\
\hline Murder & $26 \%$ & $28 \%$ & $26 \%$ \\
\hline \multicolumn{4}{|l|}{ Manslaughter } \\
\hline Common law ${ }^{20}$ & $29 \%$ & $36 \%$ & $30 \%$ \\
\hline Diminished responsibility $^{21}$ & $25 \%$ & $19 \%$ & $24 \%$ \\
\hline Other ${ }^{22}$ & $6 \%$ & $11 \%$ & $11 \%$ \\
\hline
\end{tabular}

\footnotetext{
18 'Other' includes arson, negligence/neglect, burning/scalding, causing to fall against hard surface, struck by motor vehicle, drowning and poisoning.

${ }^{19}$ Due to problematic data in this category within the first dataset (1977-1995), this analysis is based on the parricides that took place between 1996 and 2012 ( $n=335)$.

${ }^{20}$ Manslaughter (common law) refers to all forms of voluntary and involuntary manslaughter (excluding diminished responsibility) and the Homicide Index does not distinguish between cases where the defendant is deemed to have intended to kill or cause grievous bodily harm but where there were mitigating circumstances (e.g. provocation, loss of control) and in cases where there is an absence of intention (e.g. gross negligence) ${ }^{21}$ Manslaughter (diminished responsibility) refers to specific cases of manslaughter where the defendant is deemed to have experienced an 'abnormality of mind' such that there was no 'malice aforethought' and thus cannot be held fully responsible for his/her actions at the time of the killing.

22 'Other' includes death of suspect (including taking own life) and aiding and abetting suicide.
} 


\begin{tabular}{llll}
\hline Not known & $10 \%$ & $6 \%$ & $5 \%$ \\
Not guilty by reason of insanity $^{23}$ & $5 \%$ & $0 \%$ & $4 \%$
\end{tabular}

\section{Court Outcomes and Juvenile Perpetrators}

When comparing adult with juvenile offenders, Table 8 (below) highlights that the three possible outcomes for a homicide conviction (i.e. murder, common law manslaughter and manslaughter through diminished responsibility) are very unevenly distributed. Despite a similar proportion of homicide convictions for adults and juveniles ( $80 \%$ vs. $86 \%$ ), juvenile offenders are significantly less likely to receive a verdict of manslaughter due to diminished responsibility ( $26 \%$ vs. $4 \%$ of cases). ${ }^{24}$

Table 8. Court Outcomes for Adult v. Juvenile Perpetrators of Parricide: England and Wales (1996-2012)

\begin{tabular}{lll}
\hline & $\begin{array}{l}\text { Adult-perpetrated } \\
\text { parricides }(n=312)\end{array}$ & $\begin{array}{l}\text { Juvenile-perpetrated } \\
\text { parricides }(n=23)\end{array}$ \\
\hline Murder & $26 \%$ & $30 \%$ \\
$\quad$ Manslaughter & & \\
$\quad$ Common law manslaughter & $28 \%$ & $52 \%$ \\
$\quad$ Diminished responsibility* & $26 \%^{*}$ & $4 \%^{*}$ \\
Other & $7 \%$ & $5 \%$ \\
Not known & $9 \%$ & $9 \%$ \\
Not guilty by reason of insanity & $4 \%$ & $0 \%$
\end{tabular}

* Chi-square test between adult/juvenile perpetrator and Diminished Responsibility: $\chi^{2}=5.298$, phi= -0.126 ; $d f=1, p=0.021$

\section{Court disposals for cases of parricide}

Table 9 (below) shows the range of court disposals that have been used following conviction in parricide cases, comparing male and female perpetrators (1996-2012). Overall, while the majority of perpetrators (75\%) were detained, only $44 \%$ of offenders were detained in prison (or its equivalent in the case of juveniles). This compares with the $94 \%$ of all homicide offenders that are detained in prison (ONS, 2014). Furthermore, while $62 \%$ of all homicide offenders received a sentence of life imprisonment (ONS, 2014), only $38 \%$ of parricide offenders received this sentence. Hospital Orders are widely issued in parricide cases - much more so compared with homicide cases generally (31\% vs. 6\%) (ONS, 2014). As indicated in Table 9, there are some particularly gendered contours to court disposals in parricide cases: Hospital Orders appear to be particularly used with male parricide offenders (33\% vs. 19\%) while, in contrast, more Probation Orders and Supervision Orders are issued to female offenders of parricide than male offenders ( $11 \%$ vs. $4 \%$ ).

\footnotetext{
${ }^{23}$ See Criminal Procedure (Insanity) Act 1964 (Section 5), amended by the Criminal Procedure (Insanity and unfitness to plead) Act 1991

${ }^{24}$ Note that this association may not be specific to parricide cases: analysis of court outcomes of all juvenileperpetrated homicides (1996-2004) by Rodway et al (2011) found that 50\% received a verdict of murder, $47 \%$ received a verdict of common law manslaughter and $1 \%$ received a verdict of manslaughter through diminished responsibility.
} 
Table 9. Court disposals for parricides in England and Wales (1996-2012)

\begin{tabular}{llll}
\hline & $\begin{array}{l}\text { Male-perpetrators } \\
(n=299)\end{array}$ & $\begin{array}{l}\text { Female- } \\
\text { perpetrators } \\
(n=36)\end{array}$ & $\begin{array}{l}\text { All perpetrators } \\
(n=335)\end{array}$ \\
\hline Imprisonment & $43 \%$ & $47 \%$ & $44 \%$ \\
Hospital Order and/or Restriction Order 25 & $33 \%$ & $19 \%$ & $31 \%$ \\
Fully suspended sentence & $1 \%$ & $3 \%$ & $2 \%$ \\
Probation Order/ Supervision Order ${ }^{26}$ & $4 \%$ & $11 \%$ & $5 \%$ \\
Other & $13 \%$ & $11 \%$ & $11 \%$ \\
Not known & $4 \%$ & $3 \%$ & $4 \%$ \\
Died (inc. suicide) & $3 \%$ & $6 \%$ & $3 \%$ \\
& & & \\
\hline
\end{tabular}

In summary, significant findings identified in the England and Wales Homicide Index parricide data were that female offenders were more likely to have co-offenders; female victims were more likely to be over 70 years of age; 'Mercy killings' were more likely to be recorded in cases where victims were over 70 years of age; juvenile offenders were more likely to kill fathers; adult offenders were more likely to be convicted on the mitigated grounds of 'diminished responsibility'; incidents were more likely to be recorded as an 'irrational act' when they involved (i) female victims (ii) adult offenders and (iii) one-on-one dynamics; and shootings were more likely to involve (i) male offenders and (ii) double-victim parricides.

\section{Discussion}

The findings presented here represent the first-ever national analysis of parricide in England and Wales. It highlights trends over the past 36 years and identifies particular patterns within the data regarding the gender, age and ethnicity of victims and offenders, the context of parricide incidents and the distribution of judicial outcomes and court disposals. Some of these findings are consistent with the international literature on parricide: the gendered patterns of victimisation and perpetration; the disproportionate involvement of Black victims; the frequent use of sharp and blunt instruments; the predominance of parricides involving one-on-one encounters; and the stubborn consistency of parricide over time as a proportion of family violence, regardless of wider downward trends in homicide rates.

However, in other ways, the findings presented here suggest that national contexts are influential in shaping particular parricidal encounters. For example, compared with data from the United States, parricides in England and Wales involve fewer firearms and involve fewer 'double parricides'. The related nature of these two variables is highlighted by the significant association found in this data between shooting as a method of killing and double parricides as an outcome. There are also half as many incidents that involve 'multiple offenders' in England and Wales compared with the US and Australia (see earlier).

\footnotetext{
${ }^{25}$ Hospital Order includes with or without requirement Restriction Order (Mental Health Act 1983)

${ }^{26}$ Probation Order includes without or without requirements for mental treatment, activities and/or residence
} 
Some of the statistically significant findings presented in this article support current developments in parricide theory, but they challenge others. As outlined the beginning of this article, dominant theoretical explanations in the extant literature focus on the role of mental illness, and involve the identification of distinct categories of 'juvenile' and 'adult'perpetrated parricide, and of 'fatal' and 'non-fatal' violence towards parents. This discussion will now turn to addressing what the findings here imply for current theory.

\section{Implications for theoretical development}

To some extent, the findings presented in this study support the idea that mental illness plays an important role in the perpetration of parricide, particularly in relation to more recent work that identified interactional effects with the victim's gender (e.g. see Liettu, 2009). For example, this study found significantly greater use of 'Irrational act' as a recorded 'circumstance' for matricides compared with patricides. However, it is important to remain cautious about the suggestion that mental illness 'explains' parricide. The evidence presented here still suggests that most parricides are not the product of mental illness: the majority of cases were not identified as an 'irrational act', were not mitigated on the grounds of diminished responsibility and did not conclude with the issuing of a Hospital Order. This was particularly the case with juvenile offenders who, in comparison with adult offenders, were significantly less likely to have their offence identified as an 'irrational act' and were significantly less likely to receive a conviction for manslaughter on the grounds of diminished responsibility. While the findings presented here could be considered to support Heide's (2013) assertion that mental illness plays a greater role in adult-perpetrated parricide (compared with juvenile-perpetrated parricide), it may also be that juvenileperpetrated parricides simply appear more 'rational' to us (including judicial decisionmakers), perhaps because of the cultural dominance of the idea that juveniles commit parricide following years of victimisation and abuse. ${ }^{27}$

The idea that fatal violence and non-fatal violence towards parents represent distinct forms of violence involving independent populations with little continuum between the two is supported to some extent by existing knowledge that mothers are much more likely to be targeted in non-fatal violence. In contrast, the findings presented here suggest the ratio between male and female parricide victims is much more symmetrical. However, almost all research on non-fatal violence towards parents has focused on adolescent perpetrators, and the research that has taken a more developmental perspective has found that, as the perpetrator's age increases, the gender of the victim is increasingly likely to be the father (Peek et al, 1985; Agnew \& Huguley, 1989). Furthermore, research into non-fatal elder abuse has found that, while mothers are still the more likely target, the mother:father ratio (at 60:40) is similarly less pronounced (Krienert et al, 2009). With so little data at present, we can only be speculative at this point. However, applying what we know about other forms of family violence, it seems unlikely that violent adolescent and adult offspring populations are as distinct as many researchers suggest, or that there is little continuum between non-fatal and fatal violence towards parents. Indeed, in the cases of intimate partner violence and child abuse, risk of homicide has been crucial in the process of constructing each as a global social problem. One consequence of maintaining a theoretical

\footnotetext{
${ }^{27}$ For example, the sensationalised case of 16 year-old Richard Jahnke Jr., who killed his father after years of childhood abuse, made the headline in Time magazine on December 13, 1982 with: "It made terrible sense" (taken from a quote from a family friend) (Boots and Heide, 2006).
} 
distinction between fatal and non-fatal violence towards parents is that it has made it difficult to insist that policymakers take each issue seriously and give them the attention and resources they deserve. Instead, non-fatal violence towards parents gets trivialised as 'teenagers kicking off', while fatal violence towards parents often gets exceptionalised as a rare event presumed to be caused by psychopathological factors intrinsic to the offender.

The differences found in the current data between juvenile and adult perpetrators instead point to different possible pathways into parricide, depending on the perpetrator's age and the corresponding age of their parent(s). The nature of motherhood and fatherhood, and thus the nature of the parent-offspring relationship, changes throughout the lifecycle, with the consequence that mothers and fathers are most at risk from parricide at different ages, and from different identified 'circumstances'. Thus, the parricidal encounter, and the source of conflict which is at its heart, is likely to be shaped by different events, concerns and pressures, depending on where in the lifecycle the family members are located (see Shon, 2009).

However, the dynamic of family relationships is also shaped by wider political and socioeconomic changes and one question that these findings raise is why has the proportion of parricides remained stubbornly persistent despite wider downward trends in homicide over the past 15 years, including domestic homicide? One answer to this question may be found in the examination of how national family policy changes (such as the elimination of education grants, the extension of school leaving age, the reduction in working family tax credits) has impacted on, and increased tensions within, families. Such forces may be contributing to increased family conflicts between the generations.

\section{Conclusions and Recommendations}

Drawing on nationally-collated statistics such as the Homicide Index is not without its challenges and limitations. The need to place parameters on the scope of the analysis has meant that this article has focused only on victims who were parents, although such parricide incidents may also involve the killing of others (including other family members, as in the Bamber case). A more detailed analysis of such cases of familicide would be a worthwhile endeavour. Furthermore, the nature of the data mean that 'attempted parricides' have been excluded, although the dynamics of such offences may usefully inform our theoretical framework of parricides, not least because whether or not a parricide is successful is often a 'chance factor' (Block, 1977) due to the skill of the offender, the health of the victim and the availability of medical assistance. The data presented here also exclude cases which may well have been parricides but where a suspect has not been identified, and therefore the incident could not be included.

Nevertheless, this article provides a vital reference point for researchers, policymakers and practitioners around the world who work in the field of family violence. It is hoped that police officers, social workers, therapists and educationalists who work in the field of family violence will find this article useful in offering a useful context to the phenomenon to help 
them make sense of their own personal caseloads. ${ }^{28}$ The global problem of family violence has received much policy attention over the past 40 years. In England and Wales, the last five years alone have seen the implementation of domestic violence (DV) protection orders, completion of the DV disclosure scheme, a formal review of police responses to DV and the allocation of additional funding for DV specialist support services (Home Office, 2015). In contrast, policymakers across all global jurisdictions have had little to say about parricide. Therefore, one challenge for all of us involves developing ways of moving parricide from the margins of family violence to a position that enables a contextualised and balanced examination of its significance to and relationship with other forms of family violence. We might also consider how strategies that have been used to position 'domestic violence' as a social problem might be used to combat fatal and non-fatal violence towards parents. For example, one way in which campaigners have ensured that domestic violence is taken seriously by policymakers is by reconstructing the problem not as a (series of) 'incidental' events of a 'personal' nature, but as part of a wider pattern of systematic violence perpetrated by particular groups against other, more vulnerable groups (see Holt, 2016). This article suggests that parricide discourse should move away from theories of psychopathology that serve to individualise and de-contextualise such incidents and instead explore continuums of violence within the family, and examine how particular sources of conflict between generations are shaped by wider social, political and developmental factors.

\footnotetext{
${ }^{28}$ For example, in England and Wales, Domestic Homicide Reviews (DHRs) now take place following a family homicide. DHRs aim to improve service responses and prevent further tragedies (Home Office, 2013). It is hoped that the findings presented here can help to inform such reviews.
} 


\section{References}

Aitkin, M.A., Francis, B.J., Hinde, J.P. and Darnell, R. (2009) Statistical Modelling in R. Oxford: Oxford University Press.

Akuffo, E., McGuire, B. E., \& Choon, G. L. (1991). Rehabilitation following matricide in a patient with psychosis, temporal lobe epilepsy and mental handicap. British Journal of Hospital Medicine, 45(2), 108-109.

Baxter, H., Duggan, C., Larkin, E., Cordess, C. \& Page, K. (2001) Mentally disordered parricide and stranger killers admitted to high-security care. 1: A descriptive comparison, Journal of Forensic Psychiatry and Psychology, 12 (2), 287-299.

Block, R. L. (1977). Violent crime: Environment, interaction, and death. MA: Lexington Books.

Boots, D. P., \& Heide, K. M. (2006). Parricides in the media: A content analysis of available reports across cultures. International Journal of Offender Therapy and Comparative Criminology, 50, 418-445.

Bourget, D., Gagné, P., \& Labelle, M. E. (2007). Parricide: a comparative study of matricide versus patricide. Journal of the American Academy of Psychiatry and the Law Online, 35(3), 306-312.

Bryant, W and Cussen, T (2015). Homicide in Australia: 2010-11 to 2011-12: National Homicide Monitoring Program Report [online]. Australian Institute of Criminology: Canberra, Australia. February 2015. Available from:

http://www.aic.gov.au/media library/publications/mr/mr23/mr23.pdf (Accessed 28 February 2016).

Condry, R., \& Miles, C. (2014). Adolescent to parent violence: Framing and mapping a hidden problem. Criminology and Criminal Justice, 14(3), 257-275.

Eurostat (2014). Crime Statistics [online]. Retrieved from:

http://ec.europa.eu/eurostat/statistics-explained/index.php/Crime_statistics

Daly, M., \& Wilson, M. I. (1994). Some differential attributes of lethal assaults on small children by stepfathers versus genetic fathers. Ethology and Sociobiology, 15, 207-217

Diem, C., \& Pizarro, J (2010) Social Structure and Family Homicides. Journal of Family Violence, 25 (5), 521-53

FBI, Federal Bureau of Investigation (2016) Uniform Crime Reports [online]. Available from: https://www.fbi.gov/about-us/cjis/ucr/crime-in-the-u.s/ (Accessed 25 February 2016)

Fegadel, A.R. \& Heide, K.M. (2015). Double Parricide: An In-Depth Look at Two Victim Homicides Involving Parents as Victims. Behavioral Sciences \& the Law, 33(6), 723-739. 
Finch, A. (2001). Homicide in contemporary Japan. British Journal of Criminology, 41(2), 219235.

Fox, J. A., \& Swatt, M. L. (2009). Multiple imputation of the supplementary homicide reports, 1976-2005. Journal of Quantitative Criminology, 25(1), 51-77.

Grattagliano, I., Greco, R., Di Vella, G., Corbi, G. M., Campobasso, C. P., Romanelli, M. C., \& Cassibba, R. (2015). Abuses and Distortions in Emotional Processes as Risk Factors for Parricide. International Journal of Criminology and Sociology, 4, 128-135.

Graubard, B. I., \& Korn, E. L. (2002). Inference for superpopulation parameters using sample surveys. Statistical Science, 73-96.

Green, C. M. (1981). Matricide by sons. Medicine, Science and the Law, 21, 207-214

Heide, K.M. (1992). Why kids kill parents: Child abuse and adolescent homicide. Columbus, Ohio: Ohio State University Press (Cloth); (1995), London, Sage Publications (paperback).

Heide, K.M. (2013) Understanding Parricide: When Sons and Daughters kill Parents. Oxford: Oxford University Press.

Heide, K.M. \& Boots, D. P. (2007) A Comparative Analysis of Media Reports of U.S. Parricide Cases With Officially Reported National Crime Data and the Psychiatric and Psychological Literature. International Journal of Offender Therapy and Comparative Criminology, 51 (6), 646-675

Heide, K. M., \& Petee, T. A. (2007a). Parricide: An Empirical Analysis of 24 Years of US Data. Journal of Interpersonal Violence, 22(11), 1382-1399.

Heide, K. M., \& Petee, T. A. (2007b). Weapons used by juveniles and adult offenders in US parricide cases. Journal of interpersonal violence, 22(11), 1400-1414.

Hillbrand, M., Alexandre, J.W., Young, J.L., Spitz, R.T. (1999) Parricides: characteristics of offenders and victims, legal factors, and treatment issues. Aggression and Violent Behavior, 4:179-190

Holt, A. (2016) Adolescent-to-Parent Abuse as a form of Domestic Violence: A Conceptual Review, Trauma, Violence \& Abuse

Home Office (2013) Multi-agency Statutory Guidance for the Conduct of Domestic Homicide Reviews (Revised 1 August 2013), London: Home Office.

Home Office (2015). 2010 to 2015 Government Policy: Violence against Women and Girls. 8 May 2015. London: Home Office. 
Jung, S. K., Lee, J. R., Kim, J. Y., Taq, G. J., Oh, I. J., \& Myoung, E. C. (2014). Analysis of Parricide and Filicide in Korea. Korean Journal of Legal Medicine, 38(2), 66-72.

Krienert, J. L., Walsh, J. A., \& Turner, M. (2009). Elderly in America: A descriptive study of elder abuse examining National Incident-Based Reporting System (NIBRS) data, 20002005. Journal of elder abuse \& neglect, 21(4), 325-345.

Liettu, A., Säävälä, H., Hakko, H., Räsänen, P., \& Joukamaa, M. (2009). Mental disorders of male parricidal offenders. Social psychiatry and psychiatric epidemiology, 44(2), 96-103.

Mayhew, P. (2001) Review of Information on Homicide: A Discussion Document. London: Home Office.

Miles, C. (2012). Intoxication and Homicide: A Context-Specific Approach. British Journal of Criminology. 52, 870-888

O’Keefe, M., Hills, A., Doyle, M., McCreadie, C., Scholes, S., Constantine, R., Tinker, A., Manthorpe, J., Biggs, S. and Erens, B. (2007) UK Study of Abuse and Neglect of Older People: prevalence survey report. London: National Centre for Social Research

ONS, Office for National Statistics (2012) Ethnicity and National Identity in England and Wales 2011 [online]. Retrieved from: http://www.ons.gov.uk/ons/dcp171776_290558.pdf

ONS, Office for National Statistics (2014) Crime Statistics, Focus on Violent Crime and Sexual Offences, 2012/13 [online]. Retrieved from: http://www.ons.gov.uk/ons/rel/crimestats/crime-statistics/focus-on-violent-crime-and-sexual-offences--2012-13/index.html

Rodway, C., Norrington-Moore, V., While, D., Hunt, I.M., Flynn, S., Swinson, N., Roscoe, A., Appleby, L., \& Shawet, J. (2011). A population-based study of juvenile perpetrators of homicide in England and Wales. Journal of Adolescence, 34, 19-28.

Parkin, W. S., \& Gruenewald, J. (2015). Open-source data and the study of homicide. Journal of interpersonal violence, 0886260515596145 . (Available ahead of print).

Shon, P. C. (2009). Sources of conflict between parents and their offspring in nineteenthcentury American parricides: An archival exploration. Journal of Forensic Psychology Practice, 9, 1-31.

Walker, G. (2016) Imagining the Unimaginable: Parricide in Early Modern England and Wales. Journal of Family History, 41 (2).

Walsh, J.A. \& Krienert, J.L. (2009), A Decade of Child-Initiated Family Violence Comparative Analysis of Child-Parent Violence and Parricide Examining Offender, Victim, and Event Characteristics in a National Sample of Reported Incidents, 1995-2005, Journal of Interpersonal Violence, 24 (9), 1450-1477 
Walsh, J. A., Krienert, J. L., \& Crowder, D. (2008). Innocence lost: A gender based study of parricide offenders, victims, and incident based characteristics in a national sample, 19762003. Journal of Aggression, Maltreatment, and Trauma, 16(2), 202-227

Weisman AM, Sharma KK (1997) Forensic analysis and psycholegal implications of parricide and attempted parricide. Journal of Forensic Science, 42:1107-1113 